\title{
Structural Effect on Hydrocarbon Trapping, North Western Nile Delta, Egypt
}

\author{
Elhamy A. Tarabees' ${ }^{1}$, Salah S. Azam² \\ ${ }^{1}$ Geology Department, Faculty of Science, Damanhour University, Damanhour, Egypt \\ ${ }^{2}$ Exploration Department, Egyptian Petroleum Research Institute, Cairo, Egypt \\ Email: etarabees@yahoo.com
}

Received 28 December 2015; accepted 22 March 2016; published 25 March 2016

Copyright (C) 2016 by authors and Scientific Research Publishing Inc.

This work is licensed under the Creative Commons Attribution International License (CC BY). http://creativecommons.org/licenses/by/4.0/

(c) (i) Open Access

\section{Abstract}

The present study aims to interpret the available data, that derived from well logs and 2-D seismic reflection data, in the area located northeast onshore Nile Delta, in order to delineate its structural styles and its relation with the basement inferences and regional tectonic, and also to detect the possible existence of hydrocarbon accumulation at the Tertiary-Quaternary sedimentary section. The study area lies between latitudes $30^{\circ} 31^{\prime}$ and $31^{\circ} 17^{\prime} \mathrm{N}$, and longitudes $30^{\circ} 38$ ' and $31^{\circ} 21^{\prime} \mathrm{E}$. Using the available well logs, the average velocity gradients are calculated at El-Wastani, Kafr El Sheikh, Abu Madi, Qawasim and Sidi Salem Formations and velocity contour maps are constructed. The available 2-D seismic sections were interpreted and utilized to construct the isochronous reflection maps to the tops of the fore-mentioned five formations. These maps were converted into depth maps. The depth maps show the predominance of three tectonic trends. The structure contour maps were used to deduce the structural elements affecting the fore-mentioned formations in the area under study. These maps reflect the abundance of the $\mathrm{E}-\mathrm{W}$ trending faults (sometimes ENE-WSW and in other times WNW-ESE), which characterize the general Mediterranean Sea trend. The second system of structural deformations is trending NE-SW (Syrian arc trend). The third type of faults is the NW-SE trending features (Red Sea faults trend). By integrating the structure contour maps together with the different kinds of maps have been done using different sources of data such as velocity data, the possible locations that can be oil traps for hydrocarbon accumulation have been detected.

\section{Keywords}

Seismic Interpretation, Seismic Reflection, Velocity Analysis, Nile Delta, Hydrocarbon Accumulation 


\section{Introduction}

The Nile Delta, is characterized by a rolling surface sloping regionally in the northern direction. The landforms in this area are influenced by several endogenic and exogenic processes. The faults morphology is clearly noted and has a direct influence on the topographic features, while folding has only a local effect on the landscape as in [1]. These endogenic morphologic features have been subsequently affected by a number of exogenic factors including both physical and chemical weathering, and the erosion by running water and seawater activities. The study area lies between latitudes $30^{\circ} 31^{\prime}$ and $31^{\circ} 17^{\prime} \mathrm{N}$, and longitudes $30^{\circ} 38^{\prime}$ and $31^{\circ} 21^{\prime} \mathrm{E}$ (Figure 1 ).

Generally the depth of the basement beneath the Nile Delta increases to the north and estimated to be more than 13,000 $\mathrm{m}$ at the present Mediterranean coast, as in [2]. The Pre-Miocene sediments in the Nile Delta are characteristically, more or less, similar to those of the Western and Eastern Deserts. On the other hand, the Mio-Pleistocene rocks, being of deltaic characteristics, are somewhat different from their counterparts in both the Eastern and Western Deserts. In addition, it was seen that the thickness of the Post-Miocene sedimentary section in the north is more than $1850 \mathrm{~m}$ of clastics sediments. The thickness of these sediments decreases southward where its thickness reaches about $1640 \mathrm{~m}$ (Figure 2).

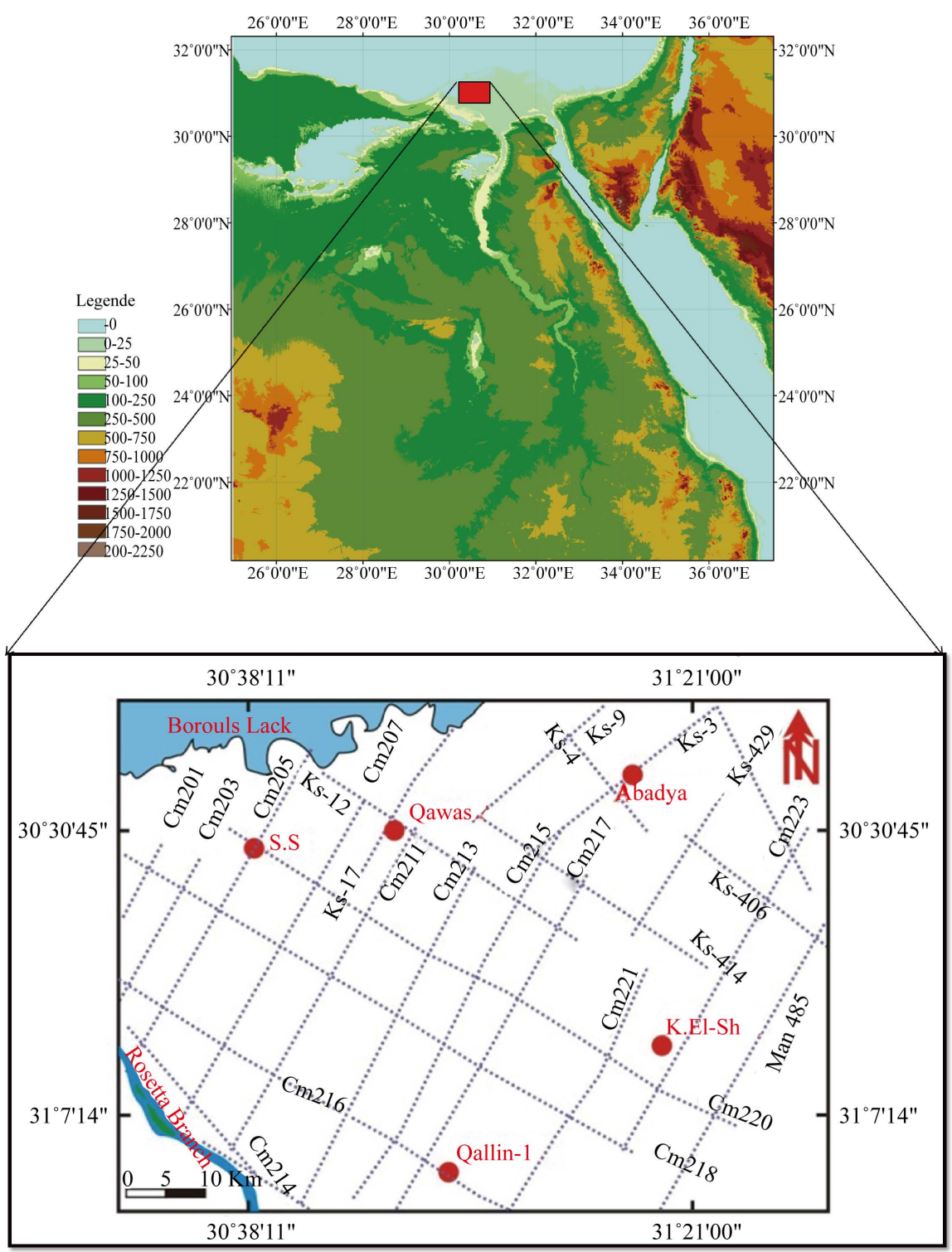

Figure 1. Location map of the study area. 


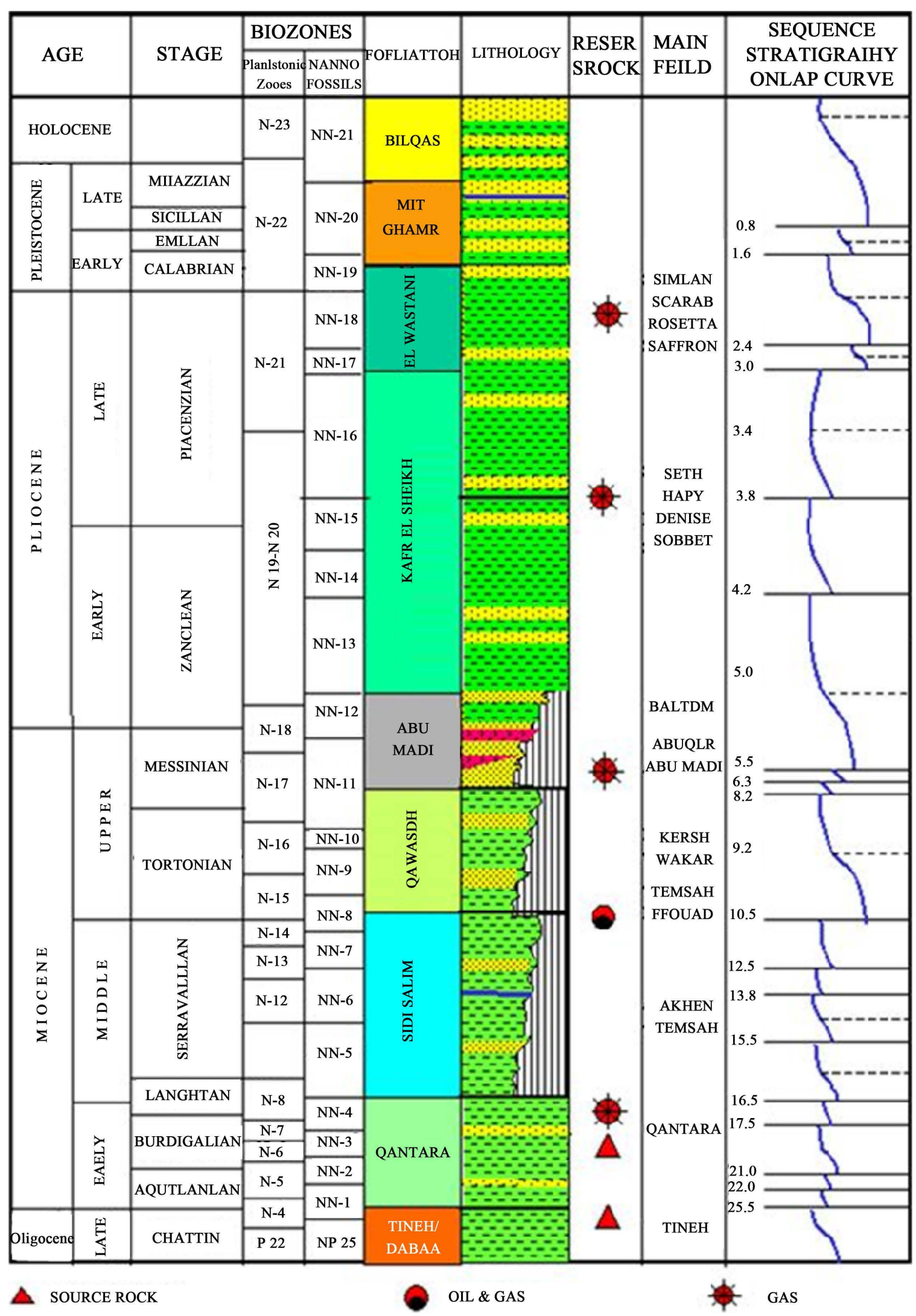

Figure 2. Generalized litho-stratigraphic column of the Nile delta region, as in [3]. 


\section{Structural Regime}

The structural patterns of the Nile Delta were studied by many authors, as in [2] [4]-[12]. All of them pointed out that the Nile Delta is an intensively faulted area. The North Delta area is tectonically separated from the Mid-Delta by a major fault zone called "hinge line", as in [13]. This hinge zone is considered as a good mark, separating the northern depositional and structural basin from the southern one. [14] concluded that, the Nile Delta is structurally controlled by three main fault trends;

1) Northwest-southeast fault trend (Gulf of Suez oblique).

2) Northeast-southwest fault trend (Aqaba oblique).

3) East-west to west northwest fault trend (parallel to the hinge zone trend).

\section{Tectonic History}

It is well known that the Nile Delta has been subjected to the general geologic events, that affected Northern Egypt during Pre-Miocene time. [15] pointed out that the tectonic history of Northern Egypt including the Nile Delta is subdivided into three main phases as follow:

1) The first tectonic phase (from Late Paleozoic to Early Mesozoic): deep structures in the Nile Delta show that the hinge line divided the delta parallel to the pre-existing $\mathrm{E}-\mathrm{W}$ fault trends.

2) The second tectonic phase was dominated by NW-SE oblique compression began in the early Late Cretaceous, culminating in the Late Cretaceous and ending in the Early Tertiary. This phase reflects the closing of the Tethys sea, as a result of moving Eurasia southeastward relative to Africa.

3) The third tectonic phase extended from the Late Eocene to Recent and characterized by three trends:

- Late Eocene to Miocene Gulf of Suez trend.

- A trend related to the development of the Miocene to Recent Gulf of Aqaba rift.

- The N-S Baltim structural fault trend.

\section{Velocity Analysis}

The process of interpretation of seismic data (stratigraphically and structurally) depends mainly on the seismic wave velocity, where the seismic velocity is being considered as the optimum bridge between a measured physical quantity (arrival time) and the desired geologic quantity (depth), Figure 3 is an example for the time depth curve as calculated from Sidi Salem well. This is because the values of velocity obtained from the stacking operation are not precise enough and must be correlated with borehole information, especially the sonic data. Therefore, the accurate knowledge of the earth's velocity function is essential.

The average velocity is simply the depth $(z)$ to a reflecting surface below a datum divided by the observed one-way reflection time $(t)$ from the datum to the reflecting surface, so that:

$$
V_{a v}=z / t
$$

If (z) represents the sum of the thicknesses of layers $z_{1}+z_{2}+z_{3}+\cdots+z_{n}$, the average velocity is then given by;

$$
V_{a v}=\frac{z_{1}+z_{2}+z_{3}+\cdots+z_{n}}{t_{1}+t_{2}+t_{3}+\cdots+t_{n}}=\frac{\sum_{i=1}^{n} z_{i}}{\sum_{i=1}^{n} t_{i}}=\frac{\sum_{i=1}^{n} v_{i} t_{i}}{\sum_{i=1}^{n} t_{i}}
$$

where: $V_{i}$ is the intervalvelocity in the $\mathrm{i}_{\mathrm{th}}$ layer.

The linear increase of velocity with depth can be expressed as:

$$
V_{y}=V_{0}+K_{y}
$$

where: $V_{y}$ is the velocity to a depth $y, V_{0}$ is the initial velocity and $K_{y}$ is the slope of the instantaneous velocity-depth line given by the equation of [16]. The average velocity is used for the time to depth conversion.

In the area under investigation, the average velocities on the formational tops are calculated from the actual time-depth relations of the wells using the Equation (2). Five average velocity gradient maps on the tops of El-Wastani, Kafr El Sheikh, Abu Madi, Qawasim and Sidi Salem Formations are constructed as shown in (Figures 4-8). 


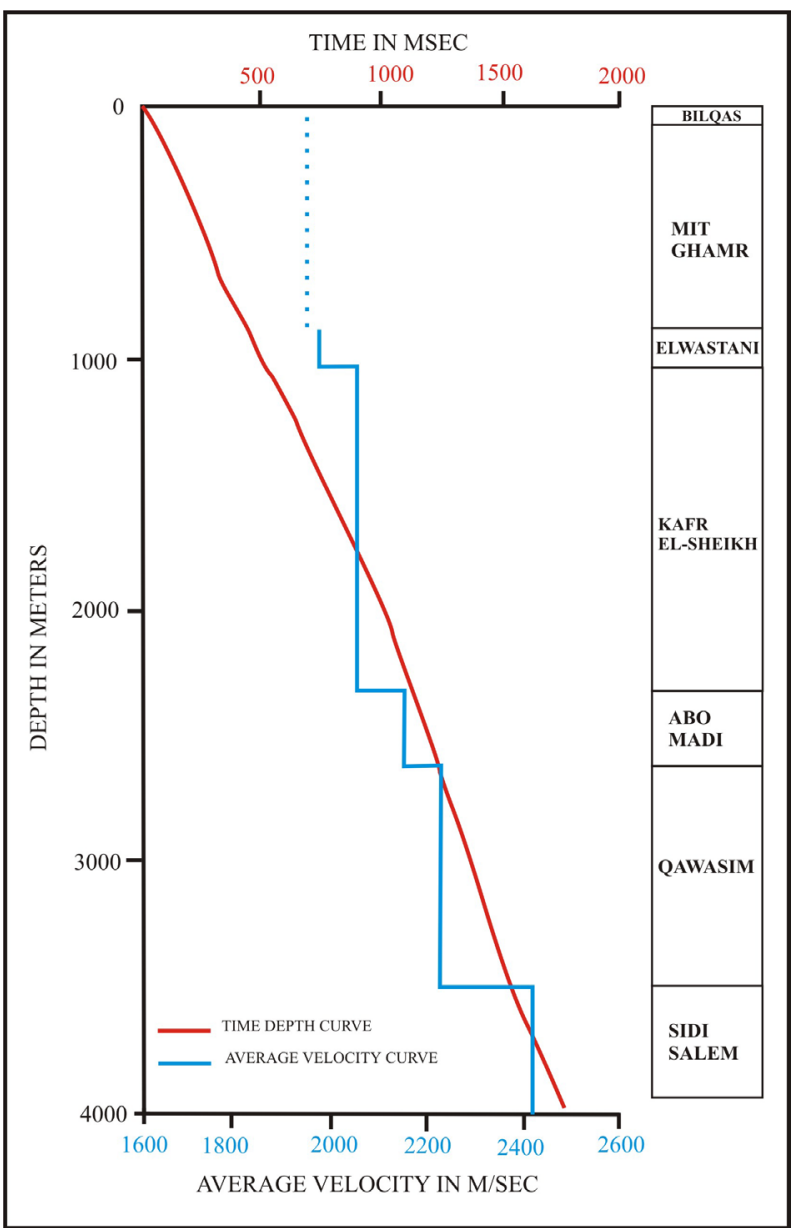

Figure 3. Time-depth curve of Sidi Salem well.

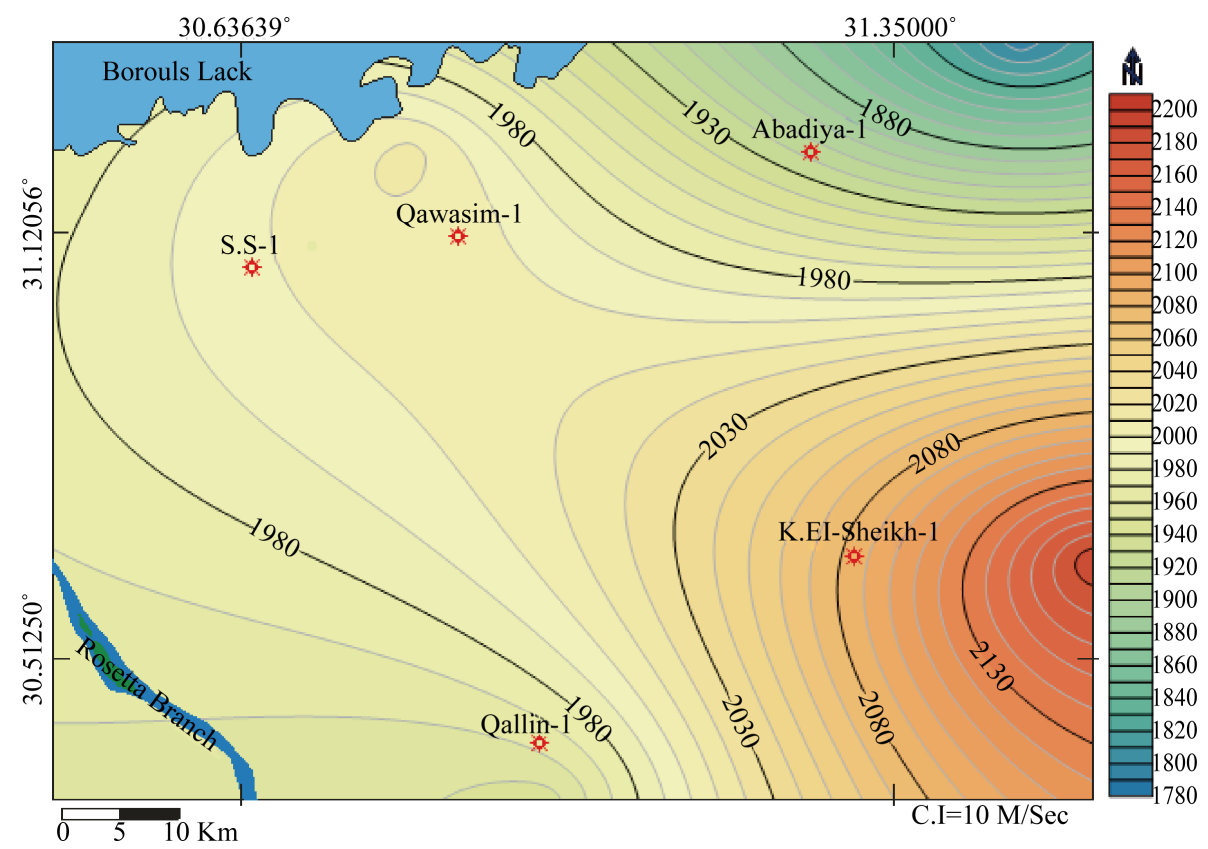

Figure 4. Average velocity gradient map on the top of El Wastani Formation. 


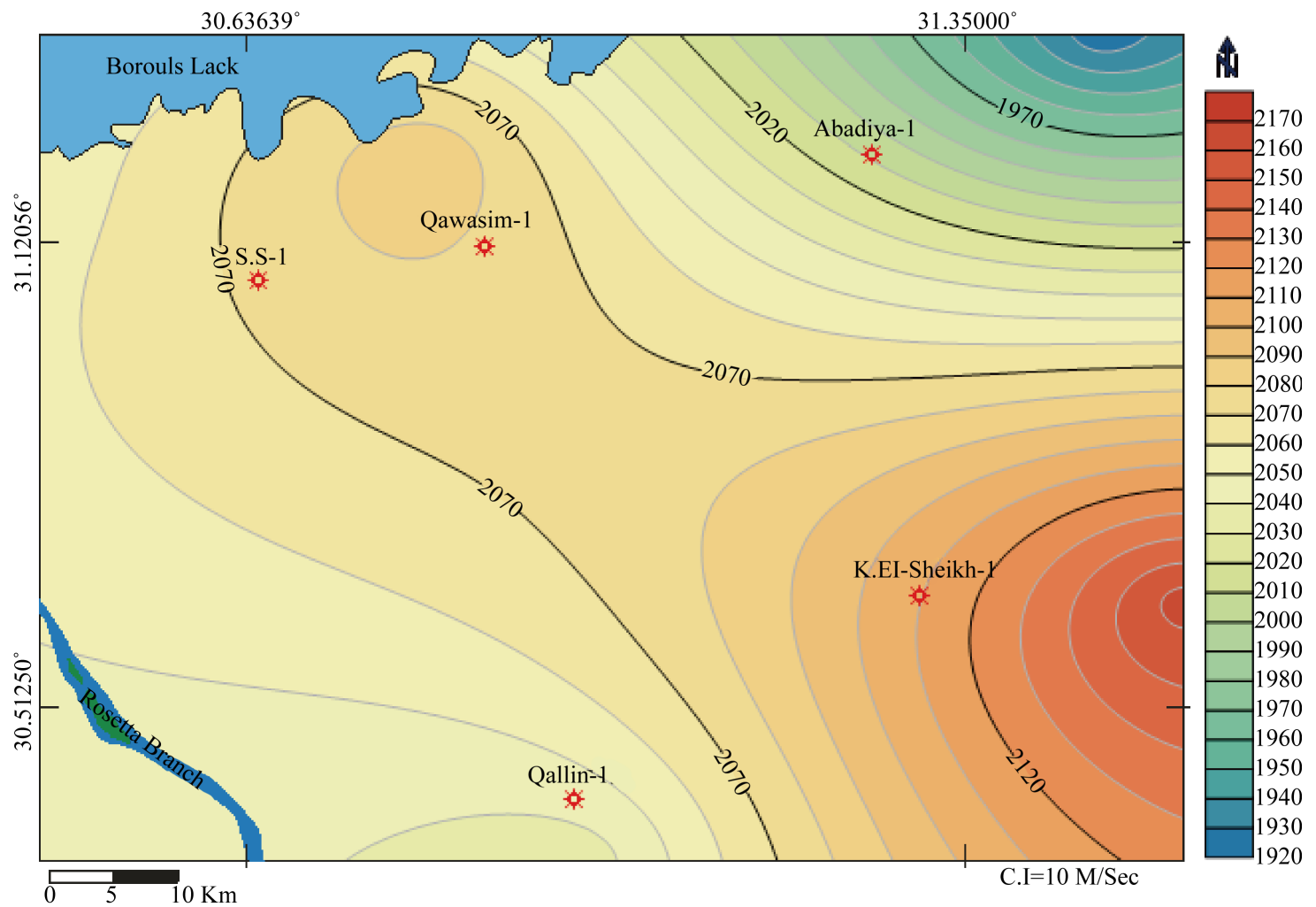

Figure 5. Average velocity gradient map on the top of Kafr El-Sheikh Formation.

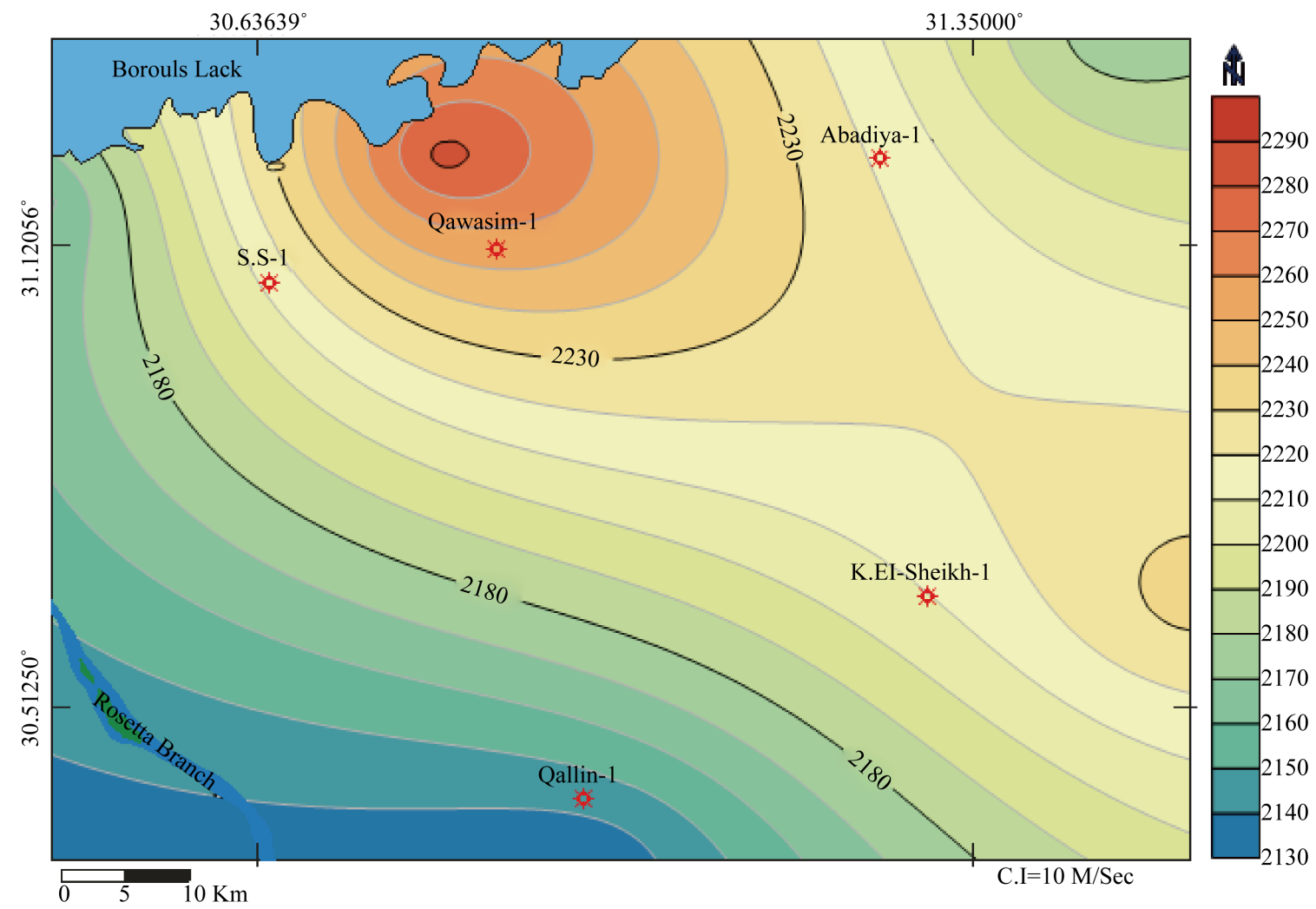

Figure 6. Average velocity gradient map on the top of Abu Madi Formation. 


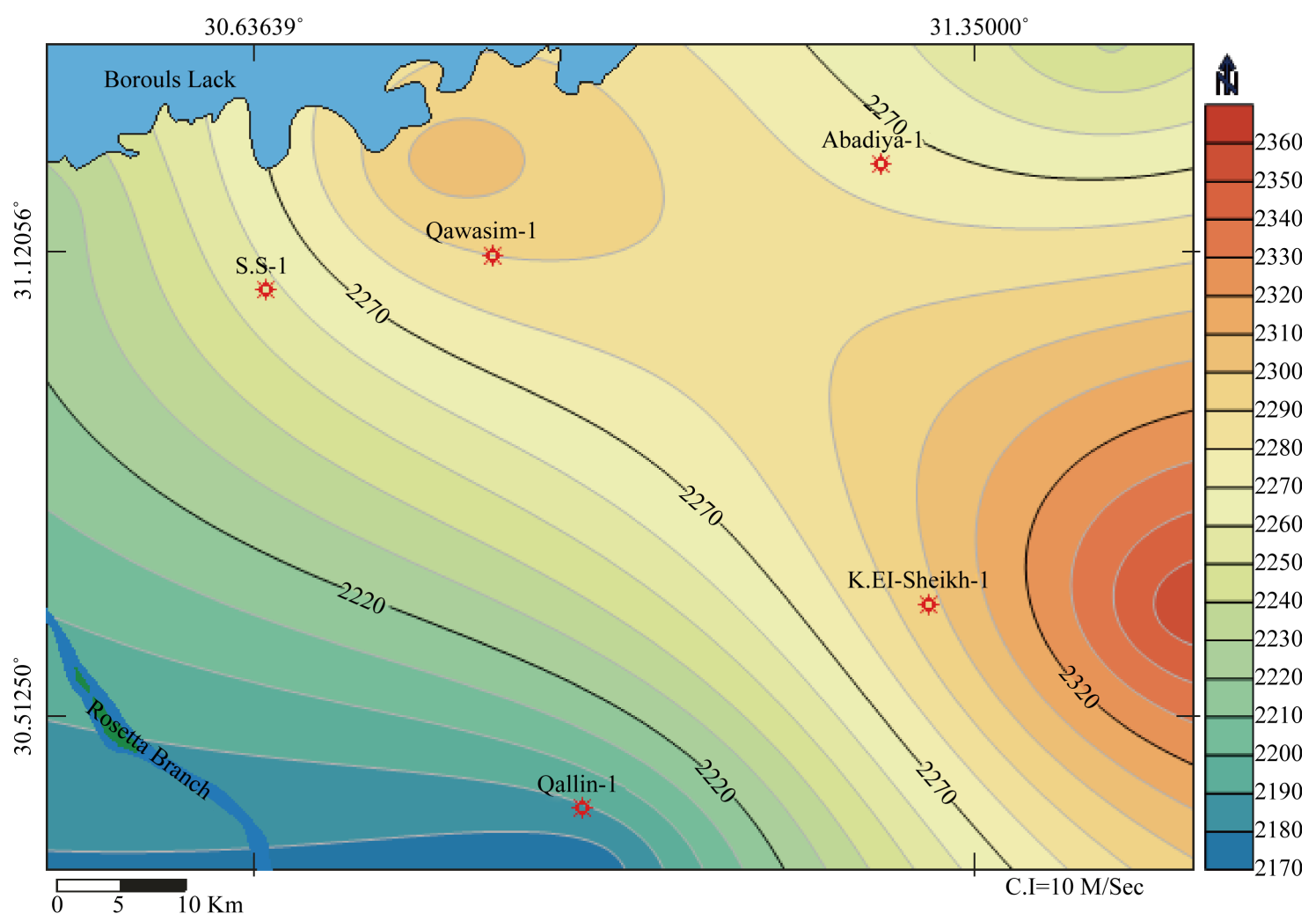

Figure 7. Average velocity gradient map on the top of Qawasim Formation.

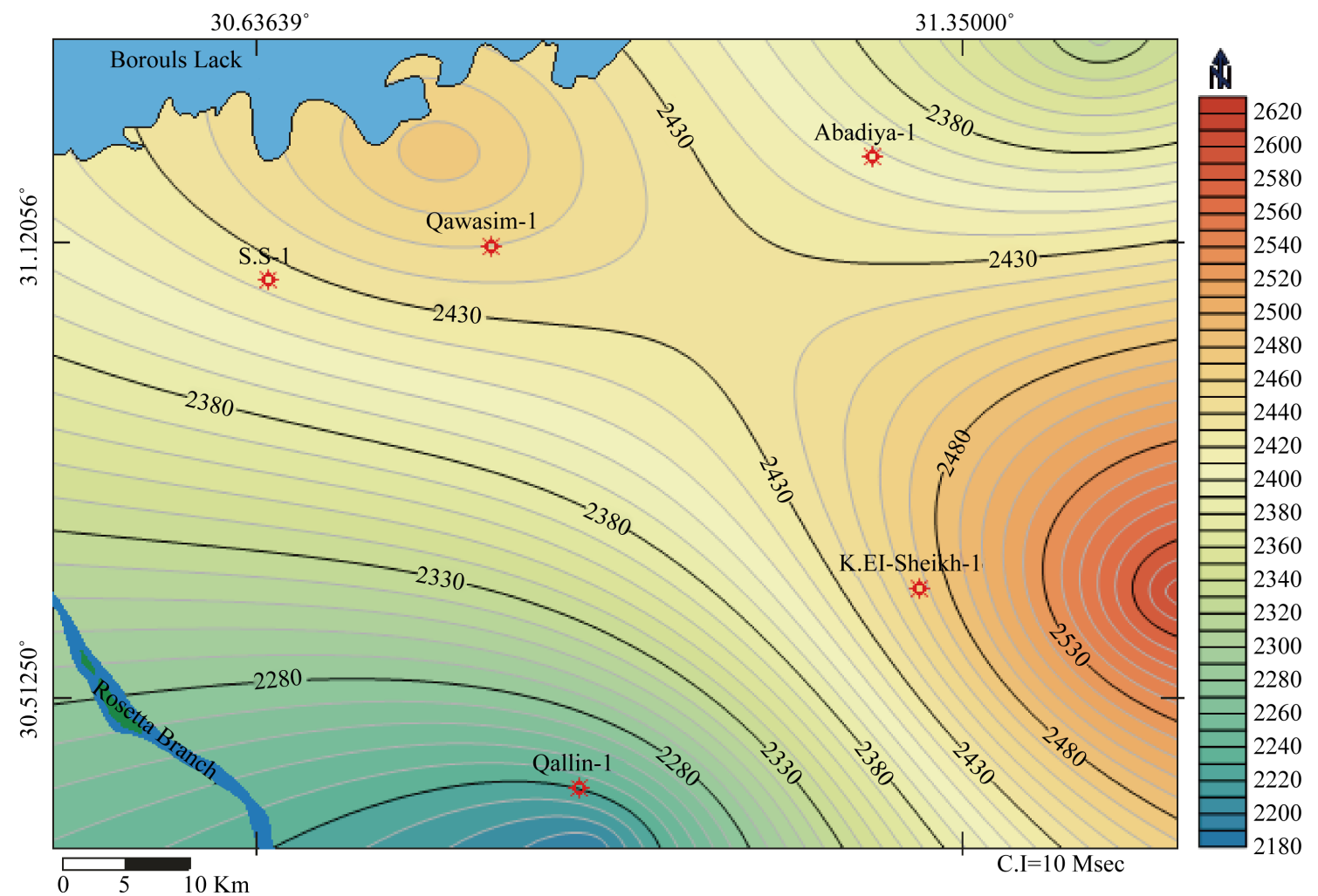

Figure 8. Average velocity gradient map on the top of Sidi Salem Formation. 
The average velocity gradient map constructed on the different tops shows a dip belt of high average velocity, trending NW-SE, that increases in the southestern direction of El-Wastani, Kafr El Sheikh, Qawasim and Sidi Salem Formations (Figures 4-8), while on top of Kafr El-Sheikh increases toward the northwestern direction (Figure 5).

\section{Seismic Interpretation}

The process of interpretation of seismic reflection data depends essentially upon the transformation of the physical responses displayed by the seismic lines into geologic information of interest concerning either the structural style or the stratigraphic regime. In order to perform such process, the seismic velocities derived from the basic time-depth relationship of the given sonic logs are used. The available seismic data in this study are variegated into seismic sections and velocity measurements. The seismic sections utilized in this investigation are twenty-three 2-D sections, as illustrated by location map (Figure 1). All of these lines were acquired by I.E.O.C. (International Egyptian Oil Company) in which a part of these lines were prefixed QAN, while the second part of these lines were prefixed MAN, and the third part of these lines were prefixed NWQ. All the seismic lines were triggered during the time interval 1975-1981. The directions of the lines are NE and NW. The used seismic sections reveal 12-fold common depth point stack. The energy source was dynamite. The energy source spread arrangements that for the lines prefixed QAN showed spacing of 10 meters, while the lines prefixed NWQ and MAN showed spacing of 20 meters. The shot interval was 150 meters and the group interval was 75 meters. Moreover, the recording filter was $10 \mathrm{HZ}$ as a low-cut filter and $125 \mathrm{HZ}$ as a high-cut filter. The sampling rate was 2 msec. for all the seismic data. The type of utilized geophones is SM-4 (10 HZ) LAND. The recording of all seismic lines was made by Seismograph Service Ltd. (SSL) (party-760) using the recording instrument type Sercel 338B with a number of traces equal 48 per record.

The seismic interpretation was conducted on the twenty-four sections that covered the study area. The interpretation of these lines involved the picking of the seismic horizons of interest (El-Wastani, Kafr El Sheikh, Abu Madi, Qawasim and Sidi Salem formations). This operation was done in steps as follows:

1) Using the lithologic logs of the wells, that penetrated the area under investigation, to define the tops of formations under study in terms of depth and converting them into two-way time using the time-depth graphs.

2) Correlation and tying of such formation times with the lines passing through their wells.

3) Plotting the two-way reflection time values on a base map.

4) Constructing the fault patterns of litho-stratigraphic tops.

5) Contouring of the two ways time (Isochronous) values and defining the structural elements (folds and faults).

Isochronous reflection maps, for the tops of El-Wastani, Kafr El Sheikh, Abu Madi, Qawasim and Sidi Salem formations were constructed in order to reflect the structural behavior on their tops (Figures 9-13).

These maps that are function of the two-way reflection times were converted into depth contour maps that are a function of the depth to the tops of the studied formations using the average velocity maps and one way time to the top of the formations. The fault structures with different orientations have been plotted as deduced from the different seismic profiles at each reflector and the possible locations for oil trapping are marked as in the pink rectangles.

The structural elements (faults and folds) were deduced from the interpreted lines by contouring the one way reflection times to the tops of the formations and average velocity of each top and transform the fault traces to the corresponding locations on the shot point location map. The structure contour maps to the tops of El-Wastani, Kafr El-Sheikh, Abu Madi, Qawasim and Sidi Salem formations are shown in (Figures 14-18). The Structure contour maps constructed on the different tops reveal general dipping toward the northeastern direction. Faults are predominant mostly in the form of dip-slip type. These faults are often trending in one of the three predominant directions as following; The first system is the E-W trending faults (sometimes ENE-WSW and in other times WNW-ESE), which characterize the general Mediterranean Sea trend. The second system of structural deformations is trending NE-SW (Syrian arc trend). The third type of faults is the NW-SE trending features (Red Sea faults trend).

\section{Conclusions}

The present paper is devoted for the treatment and interpretation of the available geological and seismic data in 


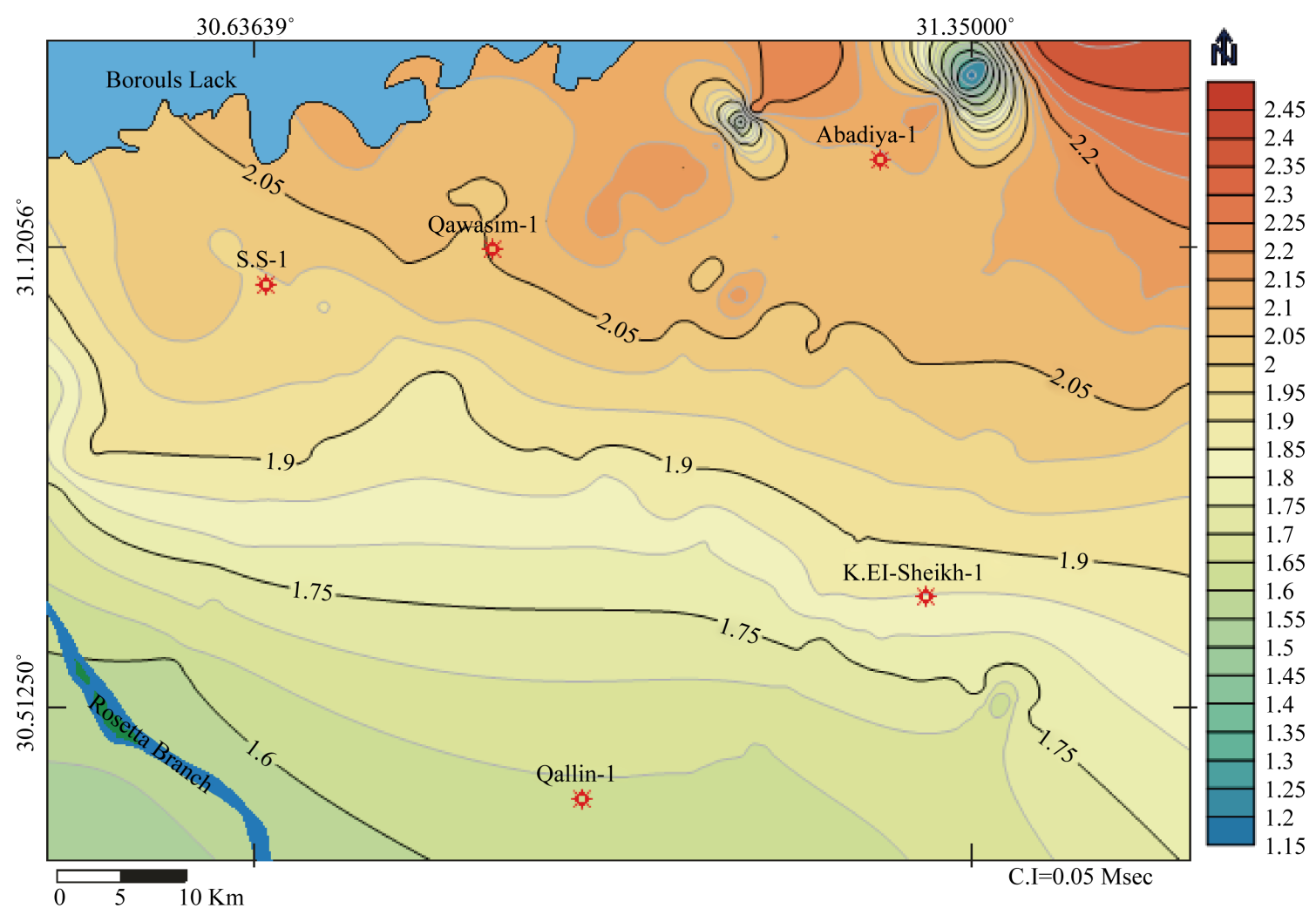

Figure 9. Isochronous reflection map on the top of El-Wastani Formation.

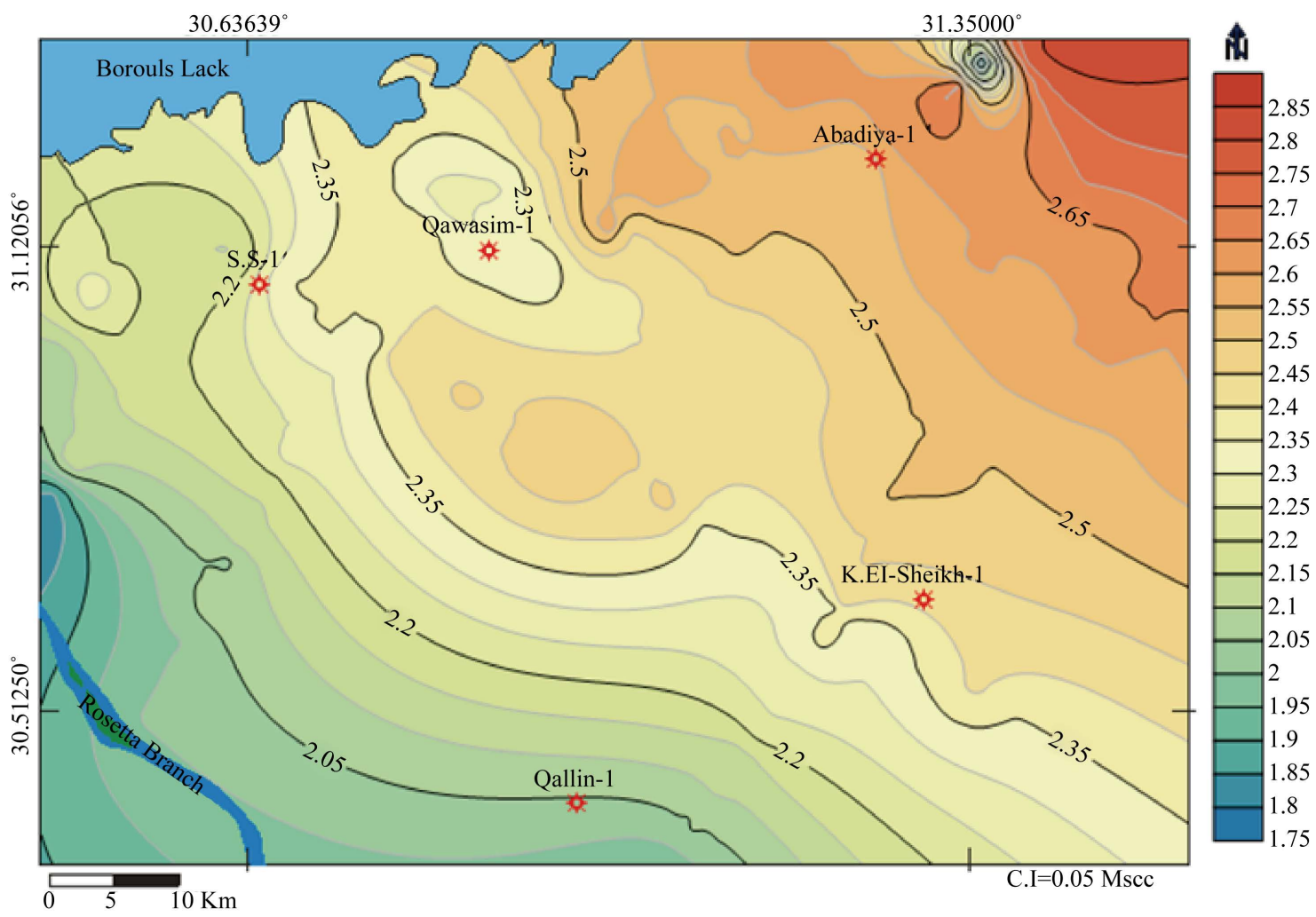

Figure 10. Isochronous reflection map on the top of Kafr El-Sheikh Formation. 


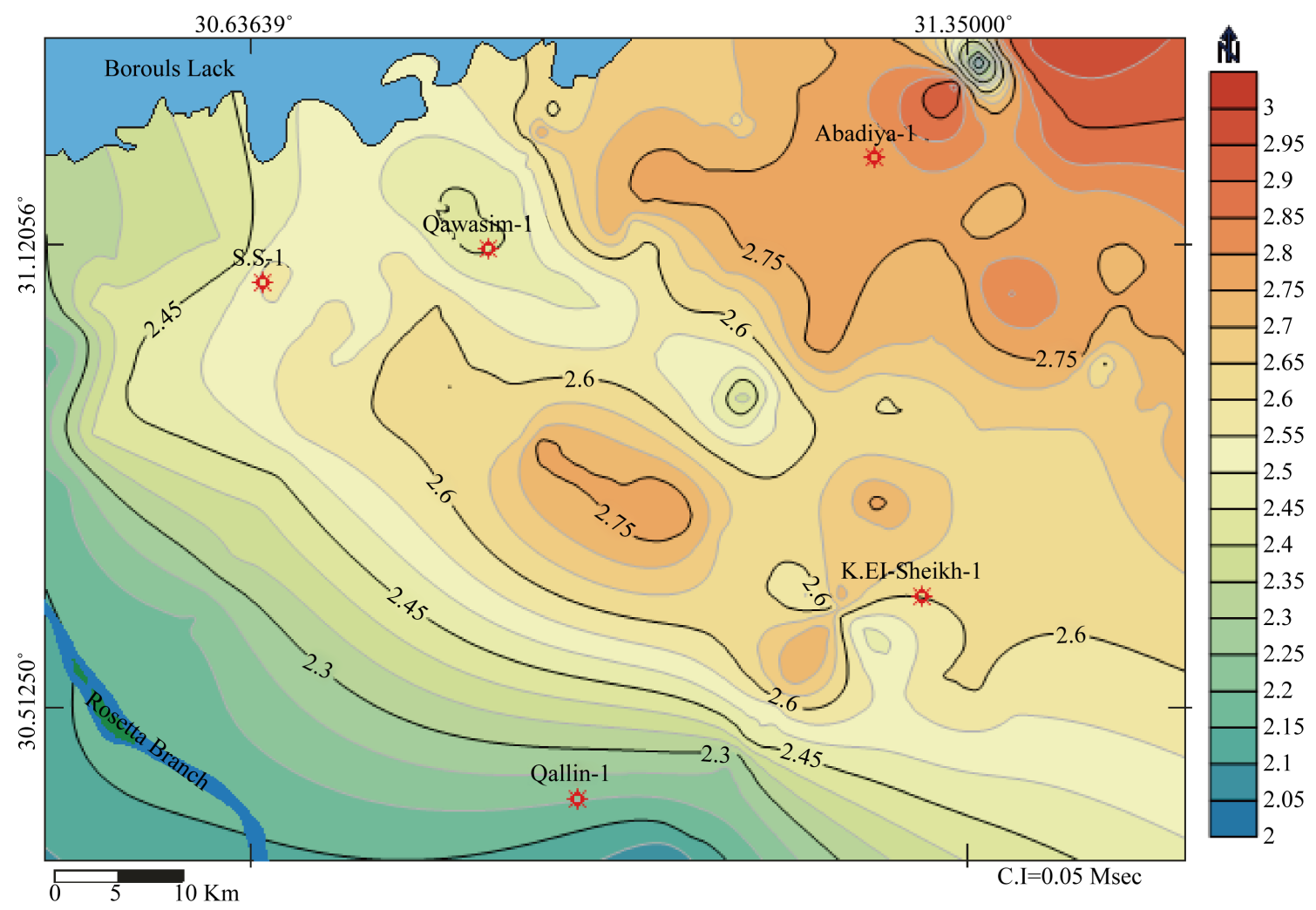

Figure 11. Isochronous reflection map on the top of AbuMadi Formation.

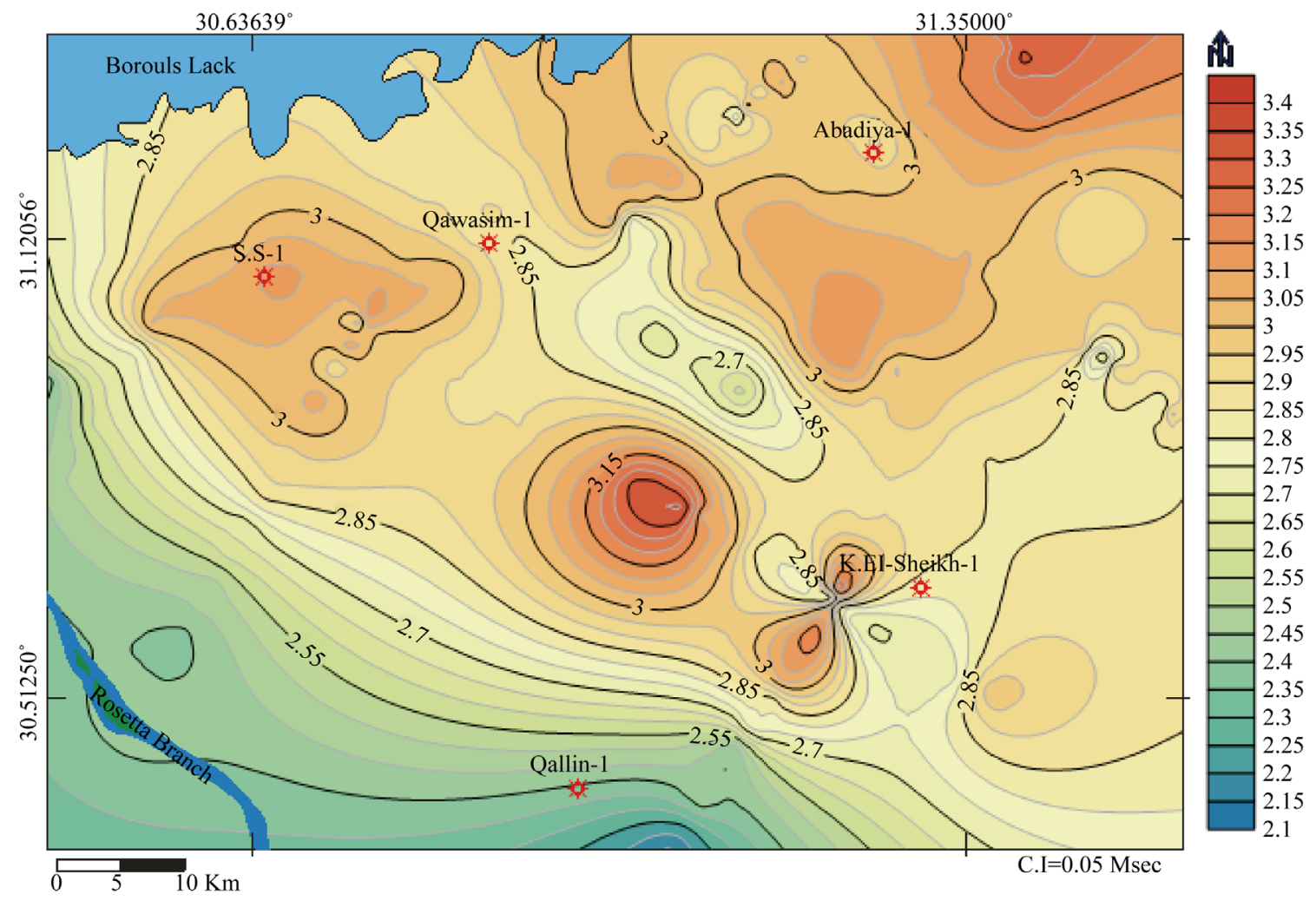

Figure 12. Isochronous reflection map on the top of Qawasim Formation. 


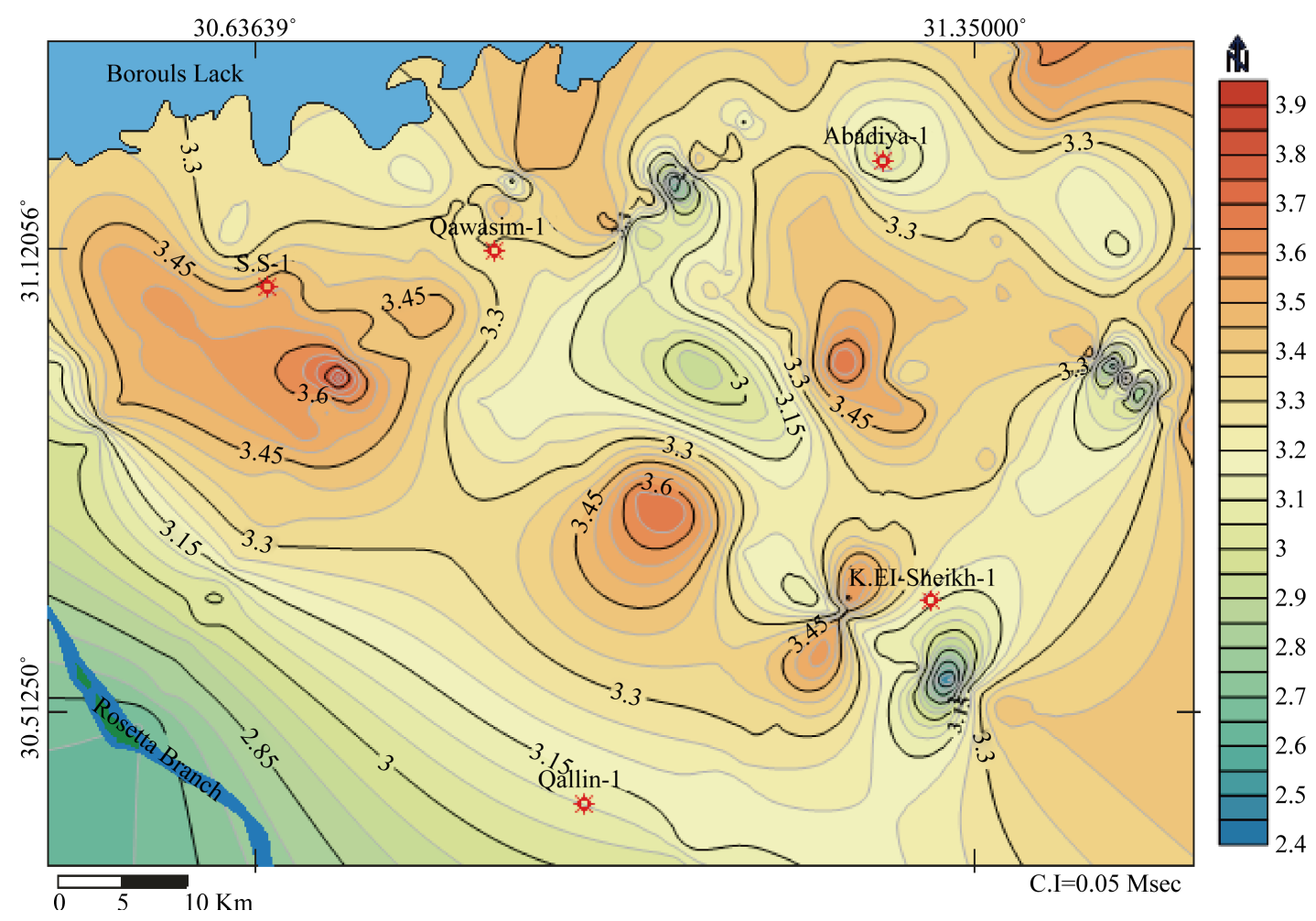

Figure 13. Isochronous reflection map on the top of Sidi Salem Formation.

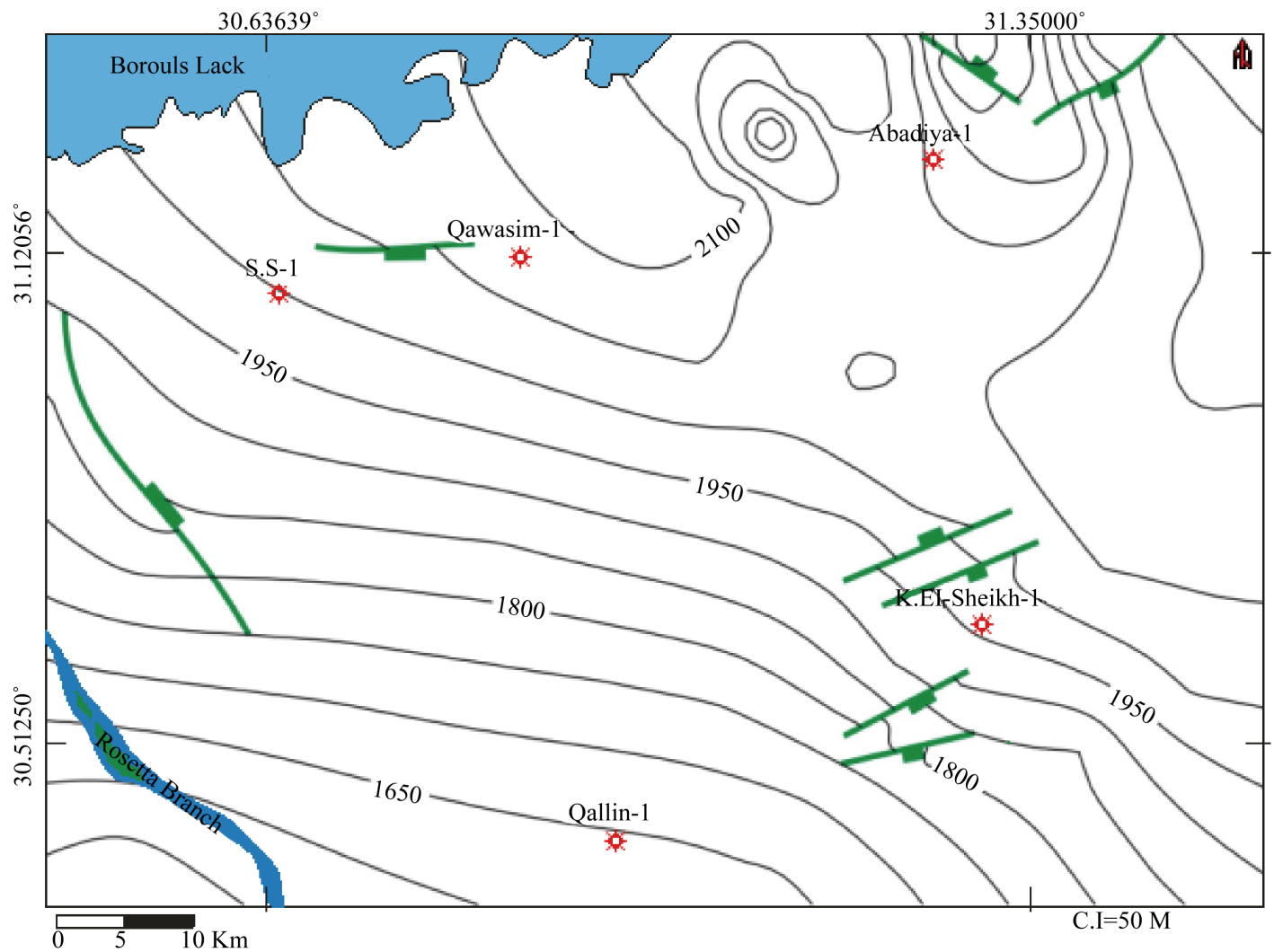

Figure 14. The Structure contour map on the top of El-Wastani Formation. 


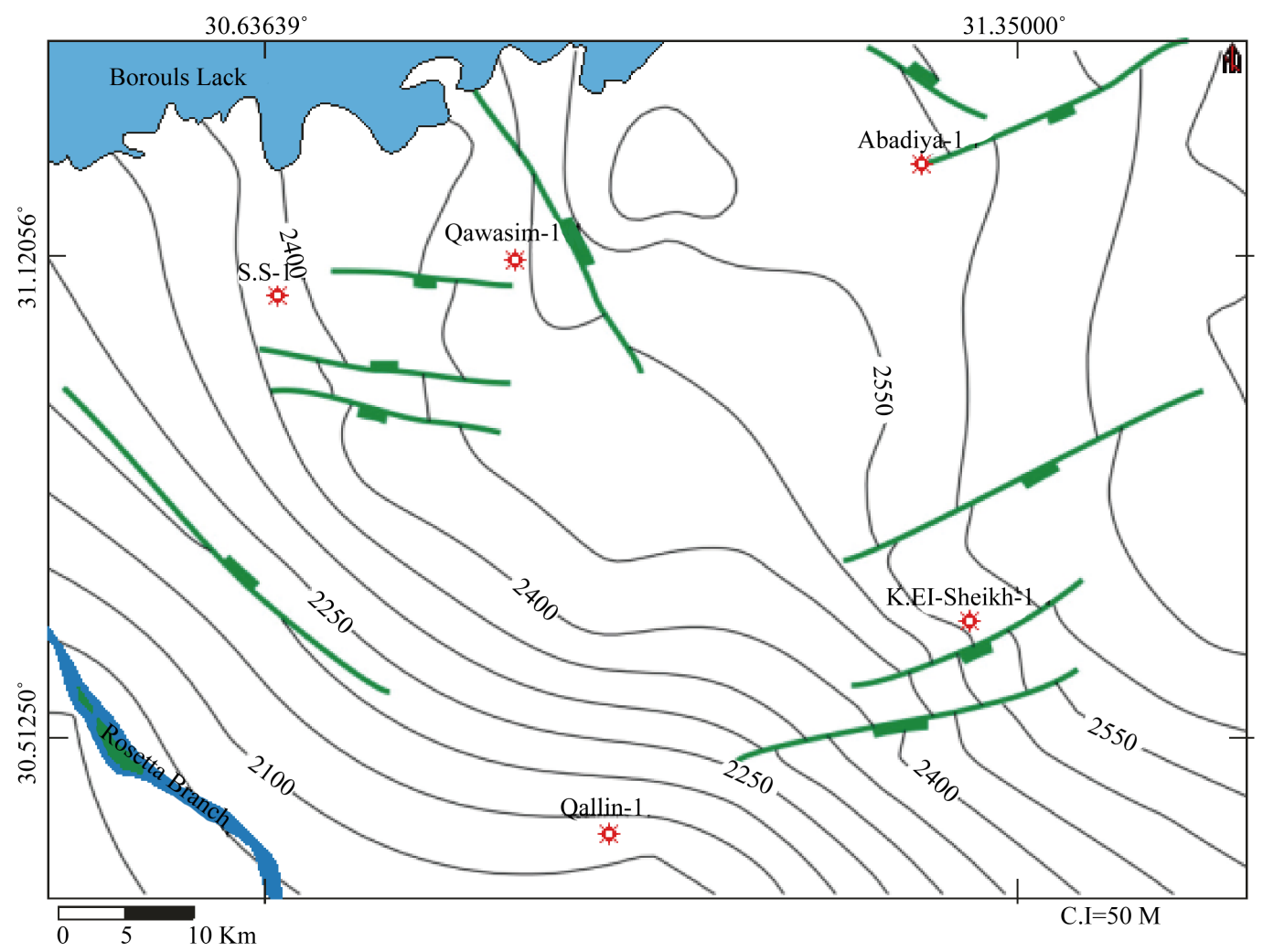

Figure 15. The Structure contour map on the top of Kafr El-Sheikh Formation.

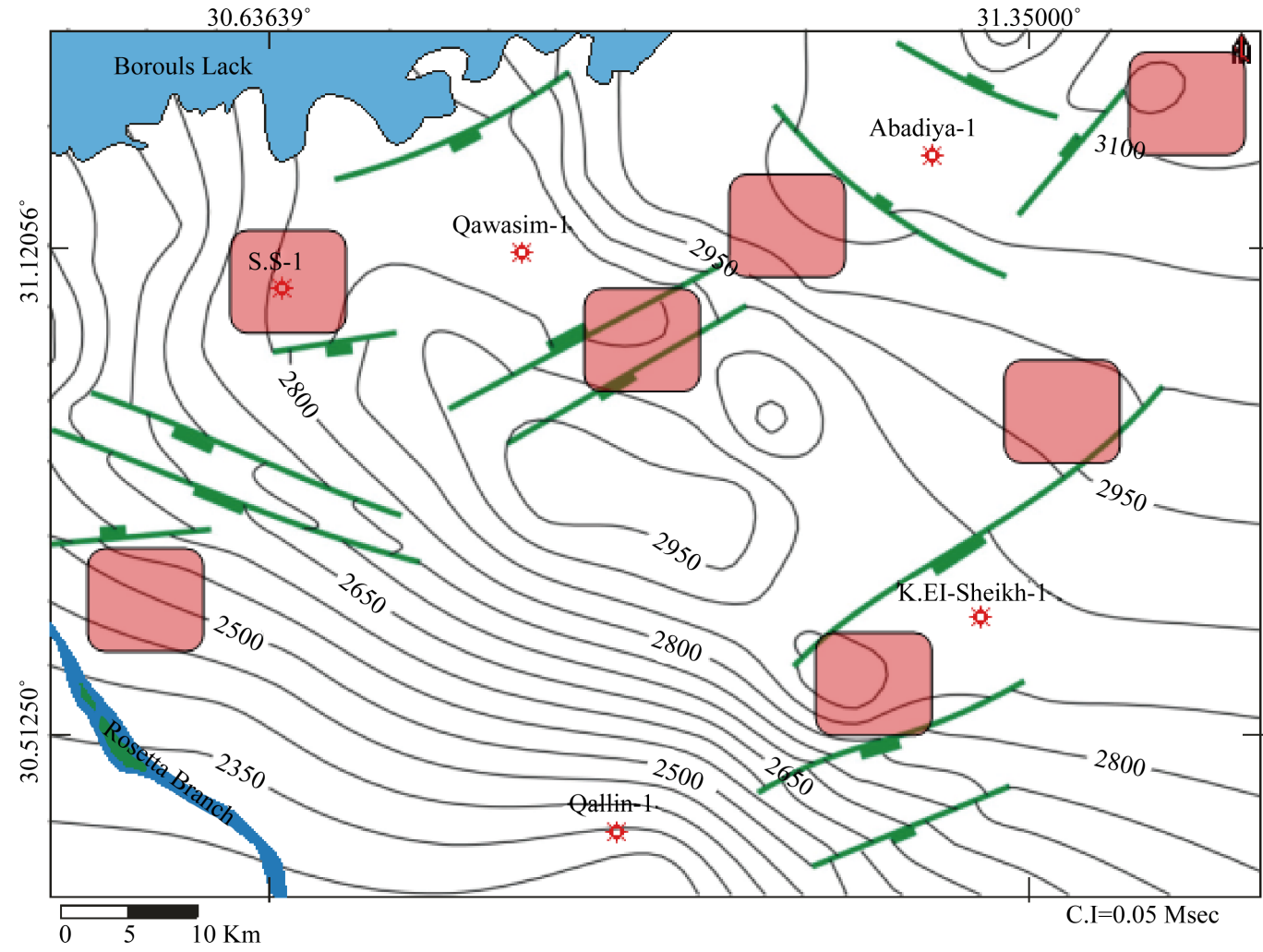

Figure 16. The Structure contour map on the top of Abu Madi Formation. 


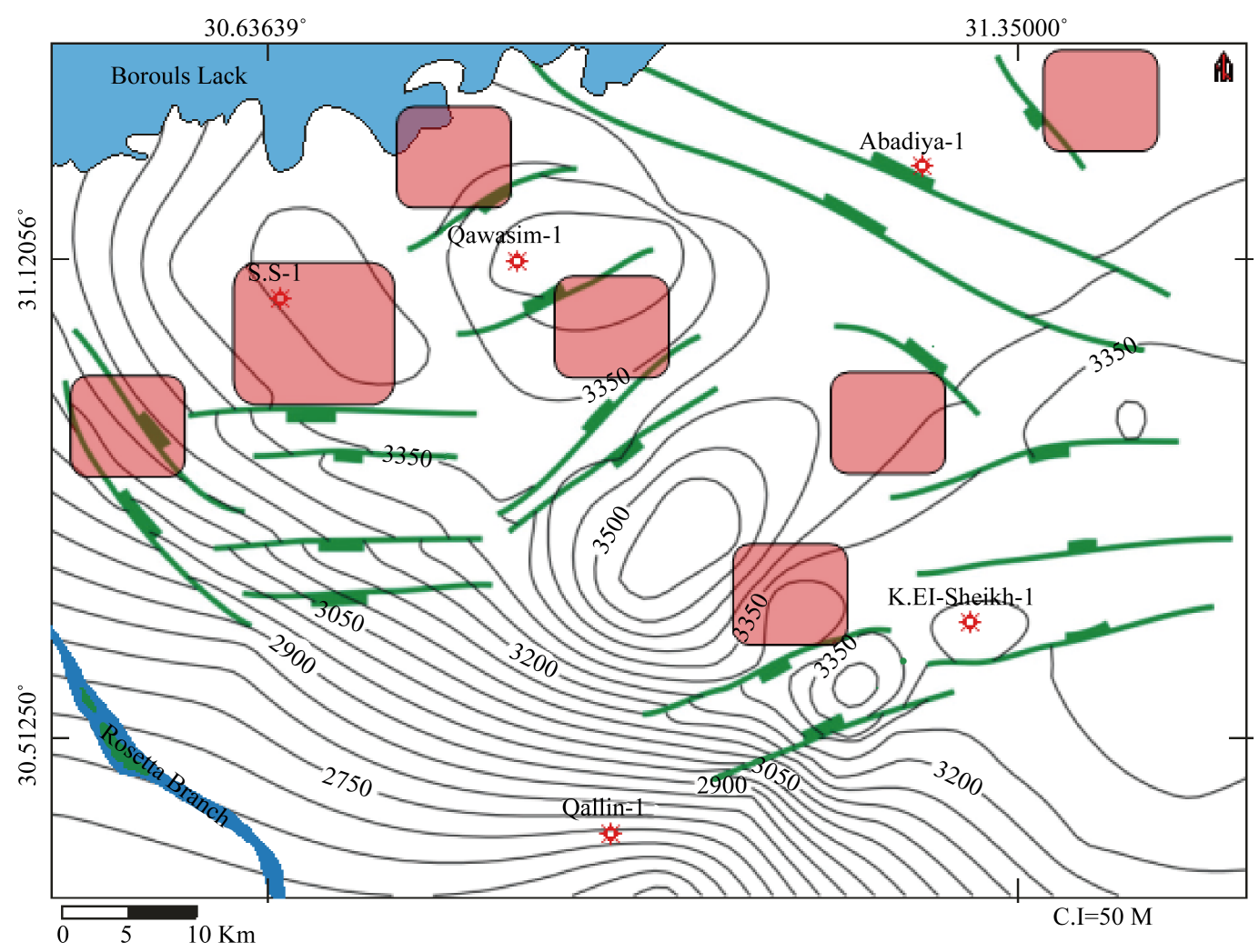

Figure 17. The Structure contour map on the top of Qawasim Formation.

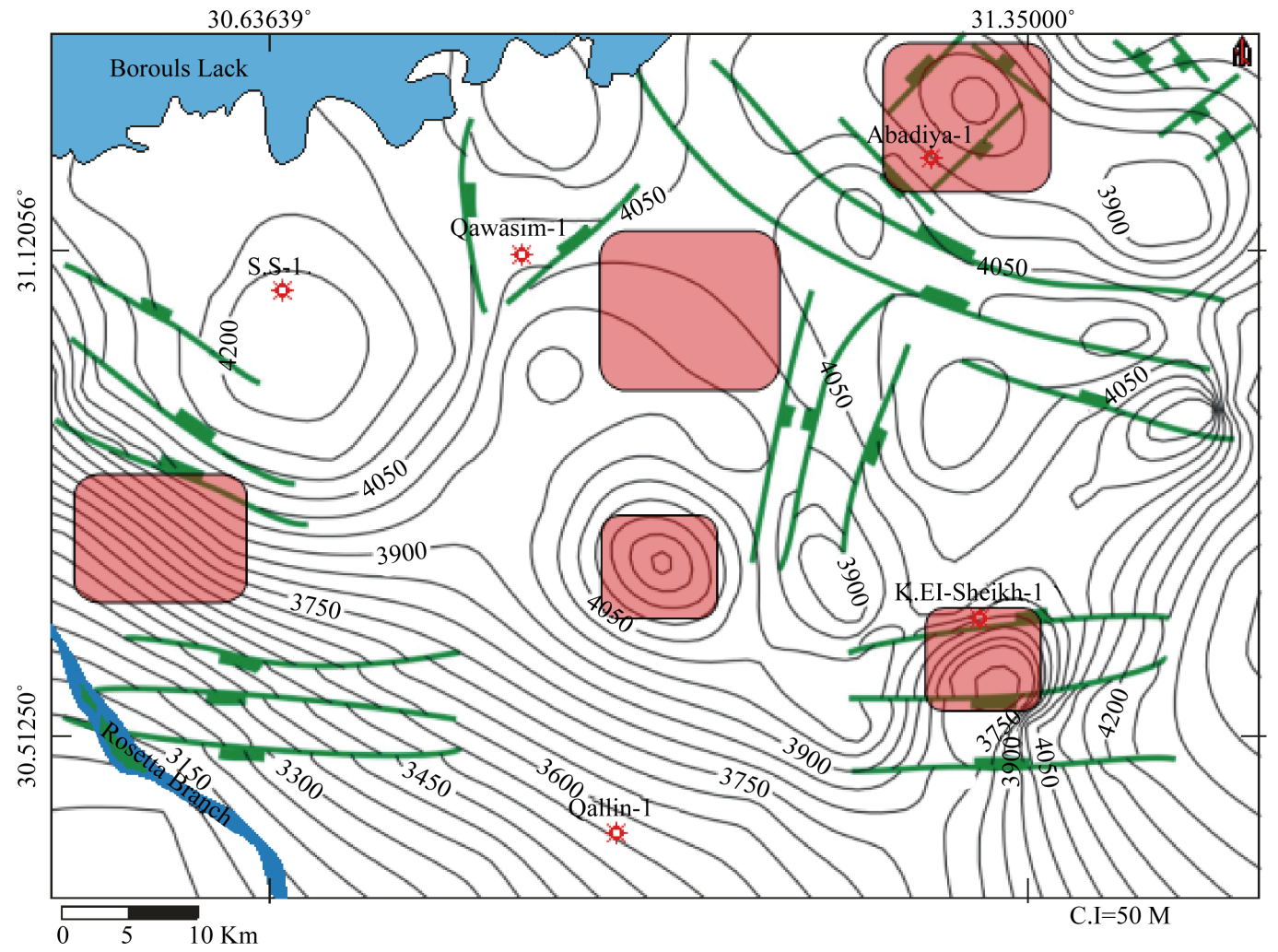

Figure 18. The Structure contour map on the top of Sidi Salem Formation. 
northwestern part of the Nile Delta, in order to conclude the structural manifestation for this area and find out the relation between the basement structure and subsurface structure and their relation with the oil traps.

The available data comprises geological and geophysical information. The geological information is derived from the composite logs of the five wells in the studied area. The geophysical data are principally seismic reflection data. The seismic data are derived from twenty-four seismic sections of different orientations covering the study area, and velocity measurements derived from the sonic logs of the drilled wells.

The average velocity gradients are calculated at the tops of El Wastani, Kafr El Sheikh, Abu Madi, Qawasim and Sidi Salem Formations. The calculated velocity values are used in constructing maps to illustrate the effect of lithologic variations on the style of velocity changes.

The interpretation of seismic sections was utilized to construct isochronous reflection contour maps on the tops of El-Wastani, Kafr El Sheikh, Abu Madi, Qawasim and Sidi Salem Formations. These maps are transformed into structure contour maps in terms of depth to the tops of formations by using the average gradient velocity maps of these tops of units. The structure contour maps were used to deduce the structural elements affecting the fore-mentioned formations in the area under study. These maps reflect the abundance of the E-W trending faults (sometimes ENE-WSW and in other times WNW-ESE), which characterize the general Mediterranean Sea trend. The second system of structural deformations is trending NE-SW (Syrian arc trend). The third type of faults is the NW-SE trending features (Red Sea faults trend).

The structure contour maps are used to detect the possible locations that can be valid for being traps for hydrocarbon accumulation. The selection of the optimum areas of closed high reliefs (to be suitable for trapping) on the tops of Abu Madi, Qawasim and Sidi Salem formations, as well as outlining them on the structure contour maps on the tops of the fore-mentioned formations. This process indicated that, there are many places available to be structural traps for hydrocarbon accumulations and can be exactly detected.

\section{References}

[1] Shata, A.A. (1965) The Geology and Geomorphology of El-Qusaima Area. Bull. Soc. Geogr. Egypte, 33, 95-146.

[2] Abu El-Ata, A.S.A. and Ibrahim, M.A. (1988) Structural-Stratigraphic Inferences of the Nile Delta of Egypt, Based on Regional and Detailed Gravity Stripping. Bull. of ICESS, 15, 119-144.

[3] Schlumberger (1984) Well Evaluation Conference, Egypt. Schlumberger Middle East Surface.

[4] Abu El-Ata, A.S.A. (1988) The Relation between the Local Tectonics of Egypt and the Plate Tectonics of the Surrounding Regions, Using Geophysical and Geological Data. E. G. S. proc. of the 6 th. Ann. Meeting, 92-112.

[5] Kellner, A., El Khawaga, H., Brink, G., Brink-Larsen, S., Hesham, M., El Saad, H.A., Atef, A., Young, H. and Finlayson, B. (2009) Depositional History of the West Nile Delta-Upper Oligocene to Upper Pliocene. AAPG International Conference and Exhibition, Cape Town, 26-29 October 2008.

[6] Bertello, F., Barsoum, K., Dalla, S. and Guessarian, S. (1996) Temsah Discovery: A Giant Gas Field in a Deep Sea Turbidite Environment, Egypt. EGPC $13^{\text {th }}$ petrol. Explor. and Produc. Conf., 1, 165-180.

[7] Gezziry, M.M. and Shandawilly, A.R. (1994) West Abu Qir field, an Interactive Geoscientific Model, Nile Delta, Egypt. EGPC $12^{\text {th }}$ Petrol. Explor. and Produc. Conf., 1, 224-239.

[8] Harms, J.C. and Wary, J.L. (1990) Nile Delta. In Said, R., Ed., Geology of Egypt, 329-343.

[9] Helmy, M. and Fouad, O. (1994) Prospective and pay Assessment of Abu Qir Bay Area, Nile delta, Egypt. EGPC $12^{\text {th }}$ Petrol. Explor. and Produc. Conf., 1, 277-292.

[10] Leila, L.M. (2014) Subsurface Geology and Reservoir Characterization of the El-Tamad Field, Northeast Nile Delta, Egypt. PhD, Thesis, El-Mansoura University, 225 p.

[11] Barakat, A. and Khairy, M. (2010) Modern Geophysical Techniques for Constructing a 3D Geological Model on the Nile Delta, Egypt. BSc., Technischen Universität Berlin, 158 p.

[12] Said, R. (1990) The Geological Evolution of the River Nile. Springer-Verlag Pub., New York, Heidelberg, Berline, 151.

[13] Marzouk, M.A. (1981) Subsurface Geological and Geophysical Studies in the Northern Area of the Nile Delta. M.Sc. Thesis, Fac. Science Alex. Univer.

[14] Sarhan, M. and Hemdan, K. (1994) North Nile Delta Structural Setting and Trapping Mechanism, Egypt. EGPC. 12th. Petrol. Explor. and Produc. Conf., 1, 1-18.

[15] Abd El-Aal, A., Price, R.J., Vaitl, D.J. and Sharallow, J.A. (1994) Tectonic Evaluation of the Nile Delta, Its Impact on Sedimentation and Hydrocarbon Potential. 12th EGPC, Petroleum Explor. and Produc. Conf. Cairo.

[16] Agocs, W.B. (1950) Computation Charts for Linear Increase of Velocity with Depth. Geophysics, 15, 227-236. 